\title{
Controlling the morphology of polycaprolactone microparticles produced by electrospraying
}

- Nguyen Vu Viet Linh

- Huynh Dai Phu

University of Technology, VNU - HCM

(Received on $23^{\text {rd }}$ December 2016, accepted on $30^{\text {th }}$ October 2017)

\section{ABSTRACT}

Electrospraying is an effective method to produce polycaprolactone microparticles for drug or protein carrier application. In this study, some factors which influenced the morphology of polycaprolactone $(P C L)$ particles were investigated by Scanning Electron Microscopy (SEM), such as polymer concentration, solvent and distance from tip to the collector. The SEM micrographs indicated that the low concentration (1\%) of PCL solution created in wrinkled and hollow semi-spheres while wrinkled spheres were formed by using higher polymer concentration (4\%). The spherical morphology was obtained when the polymer concentration was high enough (4\%) to create significant chain entanglements. In addition, chloroform and dichloromethane were good solvents to fabricate electrosprayed microspheres. Solvent mixtures such as acetone and chloroform or Dimethylformamide (DMF) and chloroform were unsuitable for electrosprayed particles since they caused unstable and heterogeneous shape. This research demonstrated that the morphology of microparticles was controlled by adjusting parameters of electrospraying to have a homogeneous and stable morphology.

Keywords: electrospray, microparticle, morphology, polycaprolactone, wrinkle

\section{INTRODUCTION}

Electrospraying has been a significant method to produce micro polymeric particles loading drug/protein. By adjusting electrospraying parameters such as polymer concentration, solvent, distance from the tip to the collector, the morphology of particles could be controlled. When the electrospraying happened, there was the competition of solvent evaporation and polymer diffusion [1]. If solvent evaporated faster, polymer chains didn't have enough time to diffuse from surface to the center of the droplets and caused the porous, hollow and wrinkled particles. During the solvent evaporation, if the chain entanglements were presented significant, the spherical particles could be generated [2-5].

Chain entanglement occurs during electrospraying process and influences the final morphology of particles. Polymer concentration is responsible for the polymer entanglement regime which dictates particles or fibers formation. At low concentration, there are no or few chain entanglements, so that the morphology of particles is a film or a semi-sphere. If there are enough chain entanglements, suitable polymer concentration, in other words, the spheres will be formed. At the high concentration, the number of chain entanglements increases highly and the particles morphology is beaded fibers, even fibers in shape [6]. The solvent properties, especially evaporation rate and dielectric constant, effects on the morphology of particles appreciably. 
When using highly evaporating solvents, the particle morphology has hollow and porous structures such as cup-like, shell-like and wrinkled shape. The solvents which have low evaporation rate make chain entanglements shrink and rearrange so that the morphology is spherical and smoother surface $[5,7,8]$.

Besides, electrosprayed PCL particles contained some suitable characteristics for drug delivery system such as drug release and the degradation of polymer particles. Because the degradation of PCL was slow, the drug release of electrosprayed PCL particles was longer $[9,10]$.

This research determined the effects of polymer concentration and distance of the tip to the collector on the morphology of electrosprayed PCL microparticles by Scanning Electron Microscopy. When we used a solvent mixture of DMF and chloroform or acetone and chloroform, PCL particles had unstable structure and were in different shapes. The electrospraying microspheres were established when the number of chain entanglements was obtained at a suitable value. The size and morphology of particles can be controlled by carefully changing electrospraying parameters, especially the polymer solution. In the next work, we will study the effects of morphology and size of microparticles on drug release in vitro.

\section{MATERIALS AND METHODS}

\section{Materials}

Polycaprolactone (PCL), Mw = $75-80 \mathrm{kDa}$ was purchased from Sigma-Aldrich. Dimethylformamide (DMF), dichloromethane (DCM) and acetone were purchased from Merck - German. Chloroform was purchased from Prolabo - France. All solvents were purified $99.9 \%$

\section{Fabrication of PCL particles by electrospraying method}

The spraying system consisted of three main components, a voltage power source with a high voltage output 9-24 kV, a mechanical syringe pump (Micropump Top-5300, Japan) with a high precision, adjustable flow rate from $0.1 \mathrm{~mL} / \mathrm{h}$ to $700 \mathrm{~mL} / \mathrm{h}$, and stainless steel needle. The anode of the voltage supply was connected to the needle on the tip of the syringe and the cathode attached to the plate covered with aluminum foil. During the electrospraying process, flow rate was fixed at $1 \mathrm{~mL} / \mathrm{h}$ while applying voltage and distance between needle and collector were adjusted to control the spraying mode and the final morphology of PCL particles. As the jet accelerated toward the target, the solvent evaporated and polymer microparticles were collected in an aluminum foil (Fig.1).

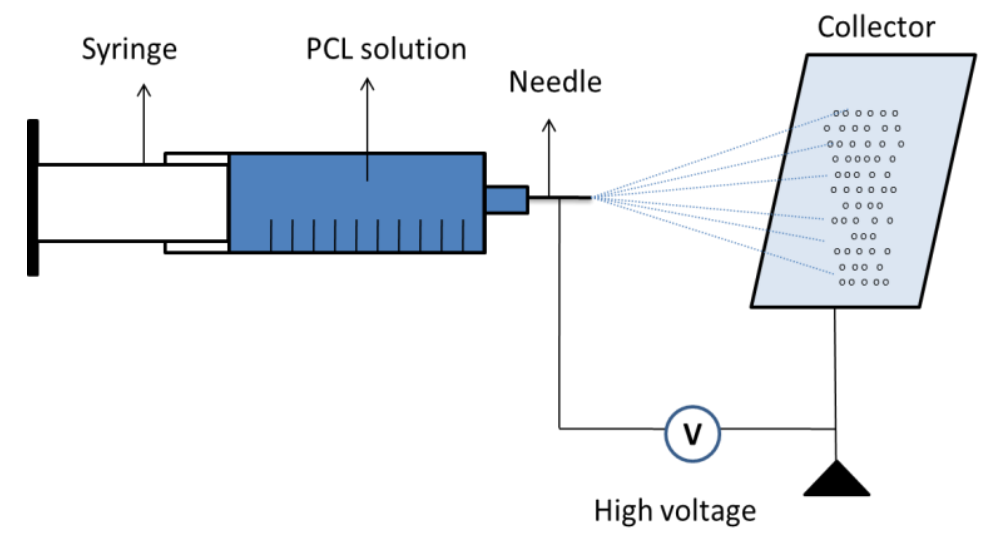

Fig. 1. Set up for electrospray process 


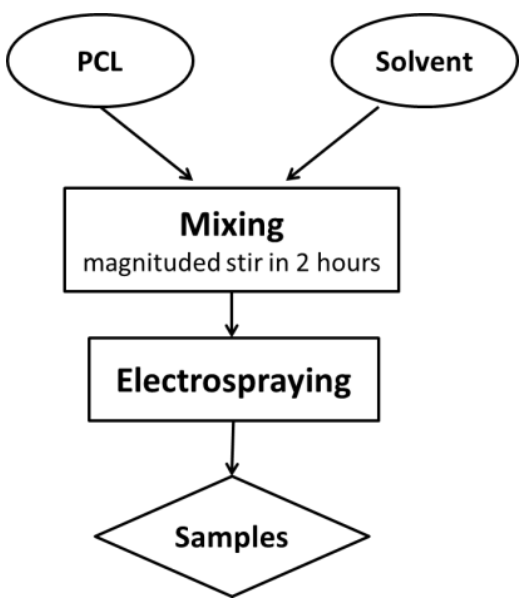

Fig. 2. Production of PCL electroprayed particles

The polymer solution was got ready by magnitude stirring of PCL and solvent in 2-3 hours. Next, the PCL solution was first added to the syringe with stainless steel needle and then the high voltage was applied to an electrosprayed system for electrospray process. After electrospraying, the polymer particles which were collected in an aluminum foil were dried by vacuum drying cabinets to completely remove solvent (Fig. 2).

\section{Morphology and charaterization}

Morphology and structure of PCL particles were determined using Scanning Electron Microscopy (SEM) (S-4800 - Hitachi - Japan). Prior to the SEM studies, dried samples were prepared with carbon tape. The accelerating voltage ranged $5 \mathrm{kV}$ during scanning.
Fourier transform infrared (FTIR) spectra of the samples were obtained on Tensor 37- Brucker at National Key Laboratory of Polymer and Composite Materials, HCMUT-VNUHCM.

\section{RESULT AND DISCUSSION}

\section{The effect of PCL concentration on particle morphology}

The SEM images showed that the low concentration of PCL solution (1\%) created hollow semi-spheres (Fig. 3A) while wrinkled spheres were formed by using higher polymer concentration (3\% and $4 \%$ PCL). The explanation is that higher polymer concentration created more intermolecular entanglements than the lower polymer concentration. Polymer concentration was responsible for the entanglement regime which dictates debris or particle formation. At low concentration (1\%), there were few chain entanglements so that the morphology of particles is a semi-sphere. The spherical morphology was obtained when the polymer concentration was high enough $(4 \%)$ to create significant chain entanglements. However, the surfaces of particles were wrinkled by the effect of solvent's evaporation. At lower PCL concentration (3\%), the size of particles was smaller $(9 \mu \mathrm{m})$ than particles of $4 \%$ PCL solution $(15 \mu \mathrm{m})$ because of restriction of chain entanglements (Fig. 3B and 3C).
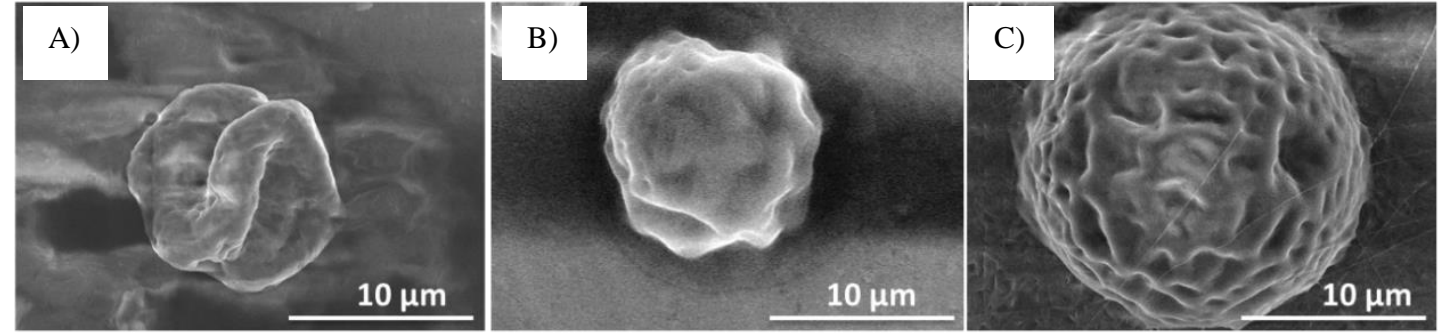

Fig. 3. SEM images of microparticles from PCL with chloroform at various PCL concentrations: (A) $1 \%$, (B) $3 \%$, (C) $4 \%$. (Voltage: $12 \mathrm{kV}$, collecting distance: $10 \mathrm{~cm}$, flow rate: $1 \mathrm{ml} / \mathrm{h}$, gauge $20 \mathrm{G}$ )

\section{Trang 132}




\section{The effect of solvent on particle morphology}

The sprayed PCL solutions were very dilute, $1 \%, 3 \%$ and $4 \%$ (w/w), so the physical properties of solutions were dominated by the solvents.

Table 1. The physical properties of solvents [11]

\begin{tabular}{|l|l|l|l|l|}
\cline { 3 - 5 } Solvent & $\begin{array}{l}\text { Boiling } \\
\text { point } \\
\mathrm{T}_{\mathrm{b}} \\
\left({ }^{\circ} \mathrm{C}\right)\end{array}$ & $\begin{array}{l}\text { Vapor } \\
\text { pressure } \\
\mathrm{P}_{\mathrm{v}} / 25^{\circ} \mathrm{C} \\
(\mathrm{kPa})\end{array}$ & $\begin{array}{l}\text { Viscosity } \\
\eta / 20{ }^{\circ} \mathrm{C} \\
(\mathrm{mPa})\end{array}$ & $\begin{array}{l}\text { Dielectric } \\
\text { constant }\end{array}$ \\
\hline Acetone & 56 & 30.8 & 0.324 & 20.7 \\
\hline Chloroform & 61 & 26.2 & 0.568 & 4.81 \\
\hline DMF & 153 & 2.7 & 0.92 & 36.71 \\
\hline DCM & 40 & 57.3 & 0.43 & 8.93 \\
\hline
\end{tabular}

Boiling point determines the speed of evaporation. At the room temperature, the solvent which had a lower boiling point such as acetone $\left(56{ }^{\circ} \mathrm{C}\right)$ and chloroform $\left(61{ }^{\circ} \mathrm{C}\right)$ were easier to evaporate than DMF $\left(153{ }^{\circ} \mathrm{C}\right)$. In case of DMF, the solvent was difficult to evaporate so that the intermolecular entanglements of PCL chain could rearrange and shrink so the particle morphology was smoother [5]. However, the results showed that the PCL particles from mixture solvent of DMF and chloroform (DMF: $\mathrm{CHCl}_{3}, 1: 3$ ), the morphology of particles was heterogeneous and unstable, like beaded fibers, spheres, elongated particles (Fig. 4A). The reason was that the dielectric constant of DMF was high (36.7), so it made the droplets at the needle charged. When the coulomb repulsion exceeded the surface

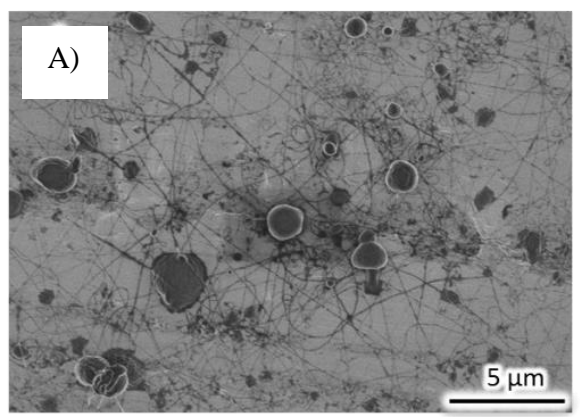

tension, the droplets became multi-jet; it meant that electrospraying was unstable. In addition, DMF could not dissolve PLA and the evaporation rate was more different with the evaporation rate of chloroform, so the mixing DMF to chloroform made unstable cone jet and collapsed particles. With the similar reason, acetone had the high dielectric constant (21) while chloroform had lower dielectric constant (4.81), so that the dielectric constant of the mixture of them also was high and this caused the multi-jet spraying mode. In the final result, the morphology of particles was irregular, such as debris, hollow semi-sphere and sticky particles (Fig. 4B). The solvent mixture made undesirable morphology of PCL particles and should not be used for electrospraying.

A mixture solvent of chloroform and acetone or chloroform and DMF caused irregular shapes of electrosprayed particles and unrepeated results. The reason was that there was a significant difference between evaporation rate of solvents and electrical conductivity, and it generated unstable and heterogeneous shape (Fig. 4). In addition, the PCL was soluble in chloroform absolutely, soluble in acetone poorly and insoluble in DMF, therefore, the solvents mixture of chloroform and acetone or DMF still dissolved PCL effectively, it generated irregular morphology of electrosprayed particles.

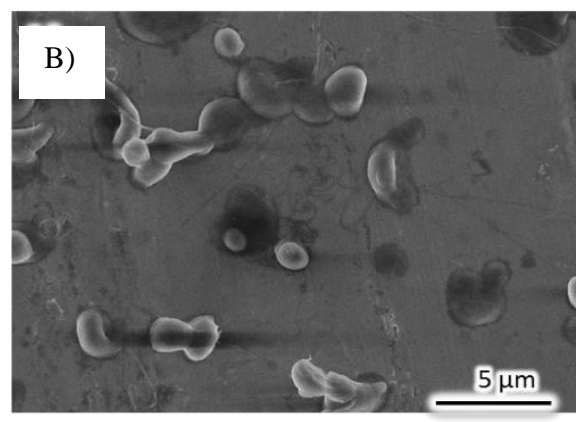

Fig. 4. Microparticles SEM micrographs of $1 \%$ PCL solutions in mixture solvents of Chloroform with acetone or DMF (A) Acetone: Chloroform, 1:3 (v/v), (B) DMF: Chloroform, 1:3 (v/v) with electrospray parameters voltage: 18 $\mathrm{kV}$, collecting distance: $18 \mathrm{~cm}$, flow rate: $1 \mathrm{ml} / \mathrm{h}$, gauge $20 \mathrm{G}$ 

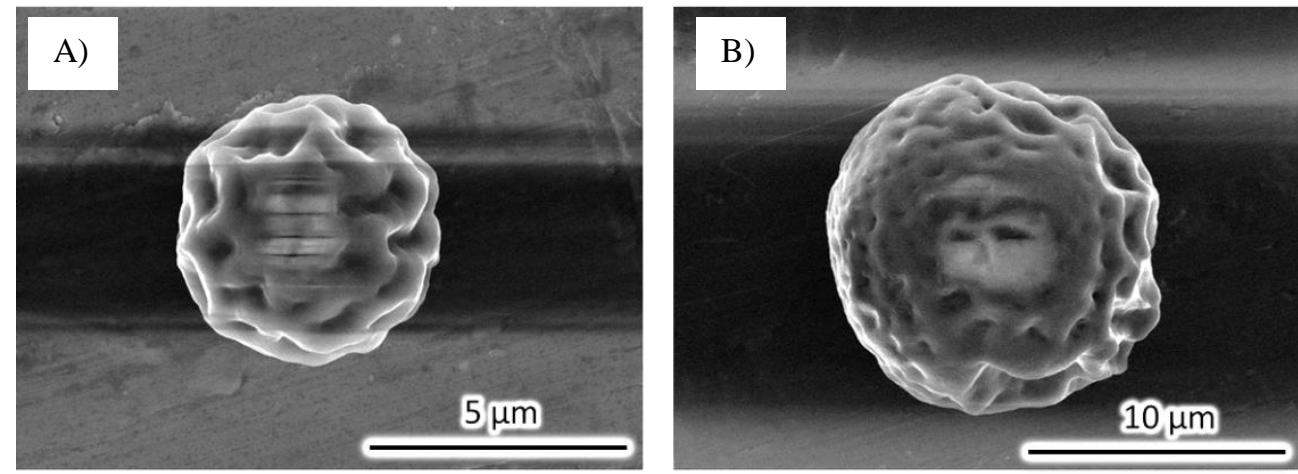

Fig. 5. SEM micrographs of $4 \%$ PCL solutions in different solvents. (A) DCM, (B) Chloroform (voltage: $12 \mathrm{kV}$, collecting distance: $15 \mathrm{~cm}$, flow rate: $1 \mathrm{ml} / \mathrm{h}$, gauge $20 \mathrm{G}$ )

DCM and chloroform had high evaporation rate because the boiling points of them were low, DCM $\left(40{ }^{\circ} \mathrm{C}\right)$ and chloroform $\left(56{ }^{\circ} \mathrm{C}\right)$. The evaporation of chloroform and DMF made the skin droplet solidified, during flying to the collector, solidified skin to move toward the droplet center so the surface particle became wrinkled. Because the evaporation of DCM was faster than chloroform, the surface of PCL/DCM particles had more wrinkles than PCL/chloroform particles (Fig. 5). Furthermore, the dielectric constant of DCM (8.93) was higher than chloroform (4.81) so that the coulomb fission could separate the droplets to smaller particles. The result was that size of PCL/DCM particles was smaller than size of PCL/chloroform particles.

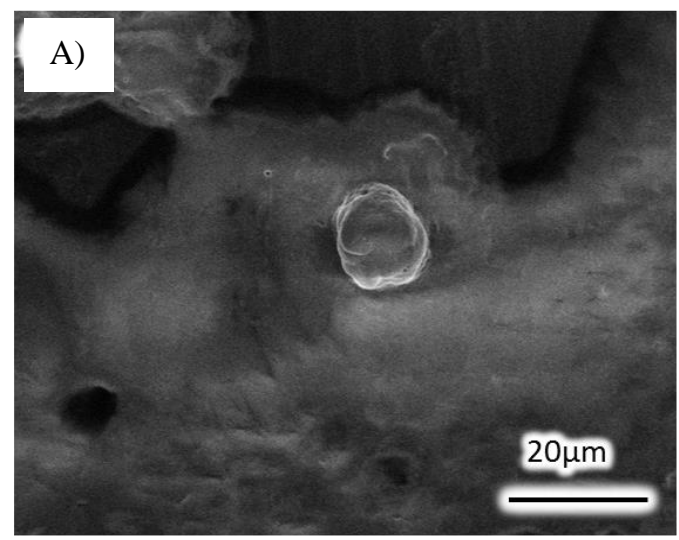

Fig. 6. Microparticles SEM micrographs of $3 \% \mathrm{PCL}$ in chloroform solution with voltage $12 \mathrm{kV}$, flow rate: $1 \mathrm{ml} / \mathrm{h}$,

gauge $20 \mathrm{G}$ and collecting distance (A) $8 \mathrm{~cm}$, (B) $15 \mathrm{~cm}$
Effect of distance from tip of needle to collector on particle morphology

The result indicated that short distance from the tip of needle to the collector $(8 \mathrm{~cm})$ generated sticky particles, even the electrosprayed particles could not to be formed (Fig. 6A). Otherwise, the spherical particles were produced when the distance from the tip of needle to the collector was $10 \mathrm{~cm}$ (Fig. 6B).

The distance between the tip of needle to the collector decided the formation of separated particles. When the distance between tip to the collector was not far enough in order to evaporate solvent completely, the particles had solvents inside and were deformed in the collector. If the solvent evaporation happened fully, the particle could solidify and form spheres in the collector.

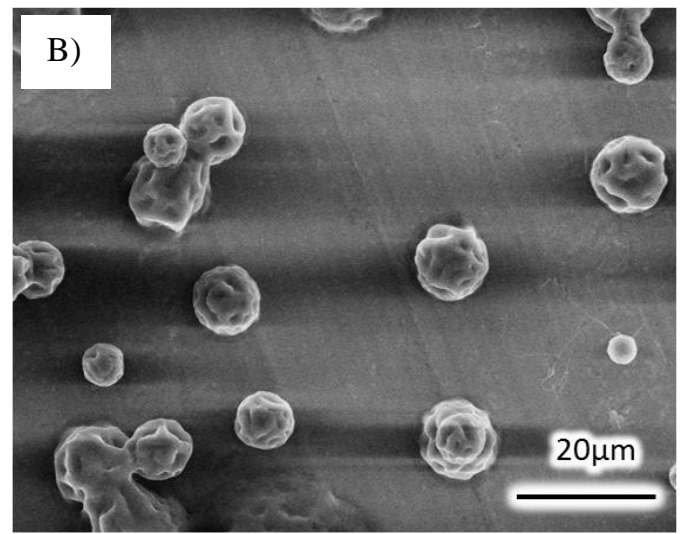

Trang 134 
Structure of electrosprayed PCL particles

FTIR spectra showed that an intense peak at $1723 \mathrm{~cm}^{-1}$ which was due to the presence of the ester carbonyl group that corresponded to the -
$\mathrm{C}=\mathrm{O}$ (stretching) in $\mathrm{PCL}$ polymer. The peaks at 2867 and $2943 \mathrm{~cm}^{-1}$ were related to the $\mathrm{C}-\mathrm{H}$ bond of saturated carbons. The small peak at $3442 \mathrm{~cm}$ was related to $\mathrm{OH}$ stretching vibrations.

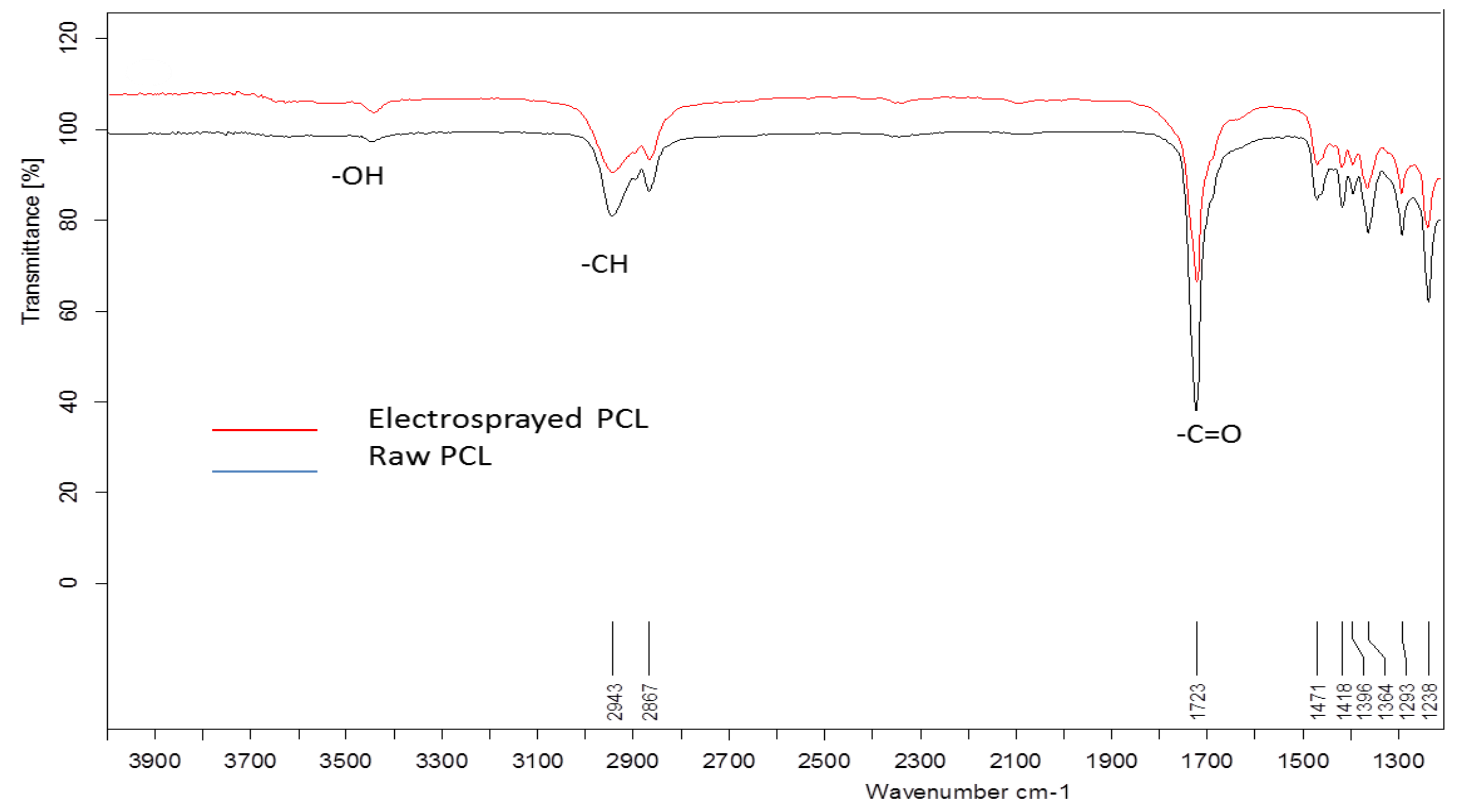

Fig. 7. FTIR spectra of raw PCL and electrosprayed PCL particles

Morover, Fig. 7 indicated that the FTIR spectrum of raw PCL was probably similar with its electrosprayed PCL, as a result, the electrospraying method didn't infuence to PCL structure during the fabrication of microparticles.

\section{CONCLUSION}

At low concentration, the morphology is a hollow particle or a semi-spherical particle because entanglement per chain is limited. At high concentration, chain entanglements are easily obtained so the morphology is a sphere. However, the surface of PCL particle is wrinkle by choosing unsuitable solvent. The solvent mixture of chloroform and DMF or acetone caused undesirable and irregular morphology of electrosprayed PCL particles. Solvents had the low boiling point, it means high evaporation, such as DCM and chloroform generated wrinkled and hollow shapes. Besides, the solvents had high dielectric constant created smaller particles than solvents had low dielectric constant.

The distance between the tip of the needle to the collector should be far enough to evaporate of solvent completely and created solid particles. The results indicated that the biodegradable PCL could be produced by electrospraying and the morphology and size of them could be controlled by processing parameter.

Acknowledgments: This research is funded by Ho Chi Minh City University of Technology $V N U-H C M$, under grant number TNCS-CNVL2016-03. 


\section{Điều khiển hình thái của hạt micro polycaprolactone được chế tạo từ phương pháp electrospray}

\section{- Nguyễn Vũ Việt Linh}

- Huỳnh Đại Phú

Trường Đại học Bách Khoa, ĐHQG-HCM

\section{TÓM TẮT}

Electrospray là môt phuoong pháp hiệu quả để chế tạo các vi hạt polycaprolactone, úng dụng làm các hệ mang thuốc hoạc protein. Trong nghiên cưu này, một số yếu tố ảnh huơơng đến hìn thái của hat polycaprolactone (PCL) đurợ nghiên cứu bởi kinh hiển vi điện tư quét (Scanning Electron Microscopy - SEM), nhu là nồng độ polymer, dung môi và khoảng cách tù đầu kim đến bản thu. Ảnh SEM chỉ ra rằng tại nồng độ thấp dung dịch PCL (1\%), tạo ra các hạt bán cầu nhăn và rỗng, trong khi các hạt cầu rỗng được tạo thành ở nồng độ polymer cao hon (4\%). Hình thái cầu chỉ đạt được khi nồng độ

Tù khóa: electrospray, vi hạt, hình thái, polycaprolactone, nếp nhăn

\section{REFERENCES}

[1]. B. Almería, W. Deng, T.M. Fahmy, A. Gomez, Controlling the morphology of electrospray-generated PLGA microparticles for drug delivery, Journal of Colloid and Interface Science, 343, 125133 (2010).

[2]. Y. Xu, M.A. Hanna, Electrospray encapsulation of water-soluble protein with polylactide: Effects of formulations on morphology, encapsulation efficiency and release profile of particles, International Journal of Pharmaceutics, 320, 30-36 (2006).

[3]. L. Ding, T. Lee, C.H. Wang, Fabrication of monodispersed taxol-loaded particles using electrohydrodynamic atomization, $J$ Control Release, 102, 395-413 (2005). polymer đủ lón để tạo các chuỗi rối đáng kể. Ngoài ra, chloroform và dichloromethane là dung môi tốt để chế tạo các hạt cầu electrospray PCL. Hỗn hợ dung môi nhu acetone và chloroform hoạc DMF và chloroform không phù hợ tạo ra các hạt electrospray, vì chúng gây nên hìn thái không ổn định và không đồng nhất. Nghiên cứu này chứng tỏ rằng hình thái của vi hạt có thể điều khiển bằng cách điều chỉnh các thông số chế tạo của phương pháp electrospraying để có hình thái đồng nhất và ổn dịn.

[4]. J. Yao, L.K. Lim, J. Xie, J. Hua, C.H. Wang, Characterization of electrospraying process for polymeric particle fabrication, Journal of Aerosol Science, 39, 987-1002 (2008).

[5]. N. Bock, T.R. Dargaville, M.A. Woodruff, Electrospraying of polymers with therapeutic molecules: state of the art, Progress in Polymer Science, 37, 15101551 (2012).

[6]. P. Gupta, C. Elkins, T.E. Long, G.L. Wilkes, Electrospinning of linear homopolymers of poly (methyl methacrylate): exploring relationships between fiber formation, viscosity, molecular weight and concentration in a good solvent, Polymer, 46, 4799-4810 (2005).

\section{Trang 136}


[7]. C.H. Park, J. Lee, Electrosprayed polymer particles: effect of the solvent properties, Journal of Applied Polymer Science, 114, 430-437 (2009).

[8]. C. Hu, J. Zhao, W. Cui, Fabrication and surface characterization of electrosprayed poly (L-lactide) microspheres, Journal of Applied Polymer Science, 128, 3177-3183 (2013).

[9]. M.A. Woodruff, D.W. Hutmacher, The return of a forgotten polymerpolycaprolactone in the $21 \mathrm{st}$ century,
Progress in Polymer Science, 35, 12171256 (2010).

[10]. A. Bohr, J. Kristensen, E. Stride, M. Dyas, M. Edirisinghe, Preparation of microspheres containing low solubility drug compound by electrohydrodynamic spraying, International Journal of Pharmaceutics, 412, 59-67 (2011).

[11]. R.H. Perry, D.W. Green, ed.Perry's Chemical Engineers' Handbook (7th ed.). McGraw-Hill. ISBN 0-07-049841-5 (1997). 